\title{
VARIABILITY ANALYSIS OF TEMPORAL AND SPATIAL ANNUAL RAINFALL IN THE MASSIF OF AURES (EAST OF ALGERIA)
}

\author{
Adel KHENTOUCHE ${ }^{I}$, Hadda DRIDI ${ }^{1}$
}

DOI: 10.21163/GT_2019. 141.03

\begin{abstract}
:
The spatial and temporal variations of precipitation in the Aures Massif of Algeria from 1974 to 2009 were investigated using a geostatistical approach. This diachronic approach did not allow a real cyclical differentiation but reveals two phases obvious distinct wet and dry, very marked. Annual rainfall variability is associated with disruption stationary in the series. The use of the rainfall index (PCI) clearly explains the state of variability and the temporal behavior of the annual rains. The climate of the region was in the semi-arid upper floor, and had considerable rainfall. However, this situation has been reversed since 1991. It is predicted that rainfall will decrease from 50 to $105 \mathrm{~mm} /$ year on altitudes and the foothills, from 13 to 50 on Saharan areas. Statistical tests reveal breaks around 1991-1994.we notice a severe drought which began in 1991. The results indicated that the spatial pattern of precipitation was primarily the local climate effect significant type, and inside the massif, altitude and latitude are the two factors that control this variability that installs and starts to take the form of climate change
\end{abstract}

Key-words: Variability, Drought, Breaking, Rain phase, Standardized index of rain.

\section{INTRODUCTION}

Precipitation is one of the most important climate factors affecting human economies and terrestrial ecosystems (Xoplaki et al., 2004; Santos et al., 2007; Pauling et al., 2006). Increasing evidence indicates that temporal and spatial variations in precipitation have been taking place at the global scale (Semenov \& Bengtsson, 2002; Haidu, 2003; Labat, 2005), regional scale (Cannarozzo et al., 2006; Khon et al., 2007; Pauling, et al., 2006) and local scale over the past few centuries (Le Quesne et al., 2006).

The variability of the time series is treated with the help of various methods based mainly on specialized programs to detect the year of rupture and the way of segmentation or dividing this time series (Haidu, 2004; Haidu \& Magyari-Sàska, 2009). In this study we have based on some statistical laws including the Hubert segmentation method (Hubert, 2000) to determine the year announcing the beginning of change in the behavior of the time series.

Algeria is a country of the subtropical zone of Northern Africa. Its climate is very different between its regions (North-South, East-West). It is of Mediterranean type on the entire North fringe that includes the coastline and the Tellian Atlas (warm and dry summers, humid and cool winters), semi-arid on highlands in the centre of the country. The precipitation is characterized by a very significant spatial and temporal variability while annual rainfall tranche decreases as one move towards southern latitudes. They fall less than $100 \mathrm{~mm}$ in the South of the Saharan Atlas. In desert regions, the spatio-temporal

\footnotetext{
${ }^{1}$ Laboratory of natural risks and area development, Earth sciences Institute, Batna 2 University,
} Algeria.05000,adel.khentouche@yahoo.com,hadda.dridi@gmail.com 
pattern of precipitation has an especially strong influence on eco-hydrological processes. In addition to the rains decrement from the North to the South, there is also a decrease from the East to the West. Mountain area is a special land space unit, with remote geographical location, large resource gradient, disaster proneness, ecological vulnerability, and other characteristics (Jansky et al., 2002). The Aures massif, which is a separate and important physical unit by its size extent, does not escape from these influences concerning the spatial distribution of precipitation nor from the global changes influences which are animated by global temperatures increase. This study aims to characterize the pluviometry and drought dynamics in the Aures massif through searching change-points and trends in time series.

\section{STUDY AREA}

It extends between the longitudes $5^{\circ} 24^{\prime}$ to $7^{\circ} \mathrm{E}$ and the latitudes $34^{\circ} 45^{\prime}$ to $36^{\circ} \mathrm{N}$. The studied zone is located in the North-East of the Algerian territory (Fig. 1) and it covers $1203 \mathrm{Km}^{2}$. It belongs to the Highlands of Constantine. The studied zone is a mountainous region belongs to the semi-arid floor and it is facing very serious problems of water lack. Precipitation is characterized by a spatial and temporal distribution very irregular from one station to another.

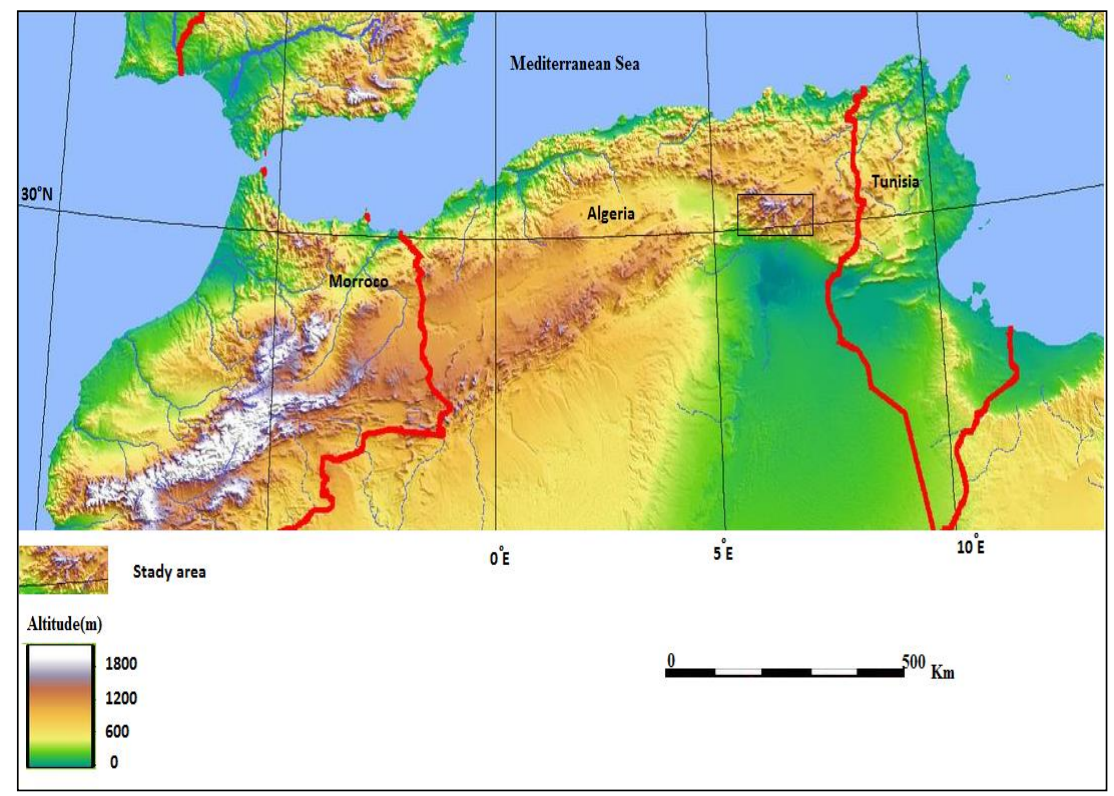

Fig.1. Situation of the studied zone.

\section{DATA AND METHOD}

Data come from two agencies responsible for the pluviometric network in Algeria: The National Agency of Hydraulic Resources and the National Office of Meteorology. To realize this study, many pluviometric stations have been retained in order to form the most complete annual data base and the most representative as possible of the studied zone. So, 32 stations have been selected with sufficient time series well distributed in the studied 
zone and strictly criticized by statistical methods (homogeneity and bridging test) to study the pluviometric regime trend. We have used many statistical tests of the change-point in the stationarity as well as the test on sequential trends in order to account the temporal and spatial evolution of the pluviometric regime. The standardized index which is widely used in the rainfall variations studies will give the distinction between the phases and the frequency of dry and humid years. The observed stations locations were shown in Fig. 2.

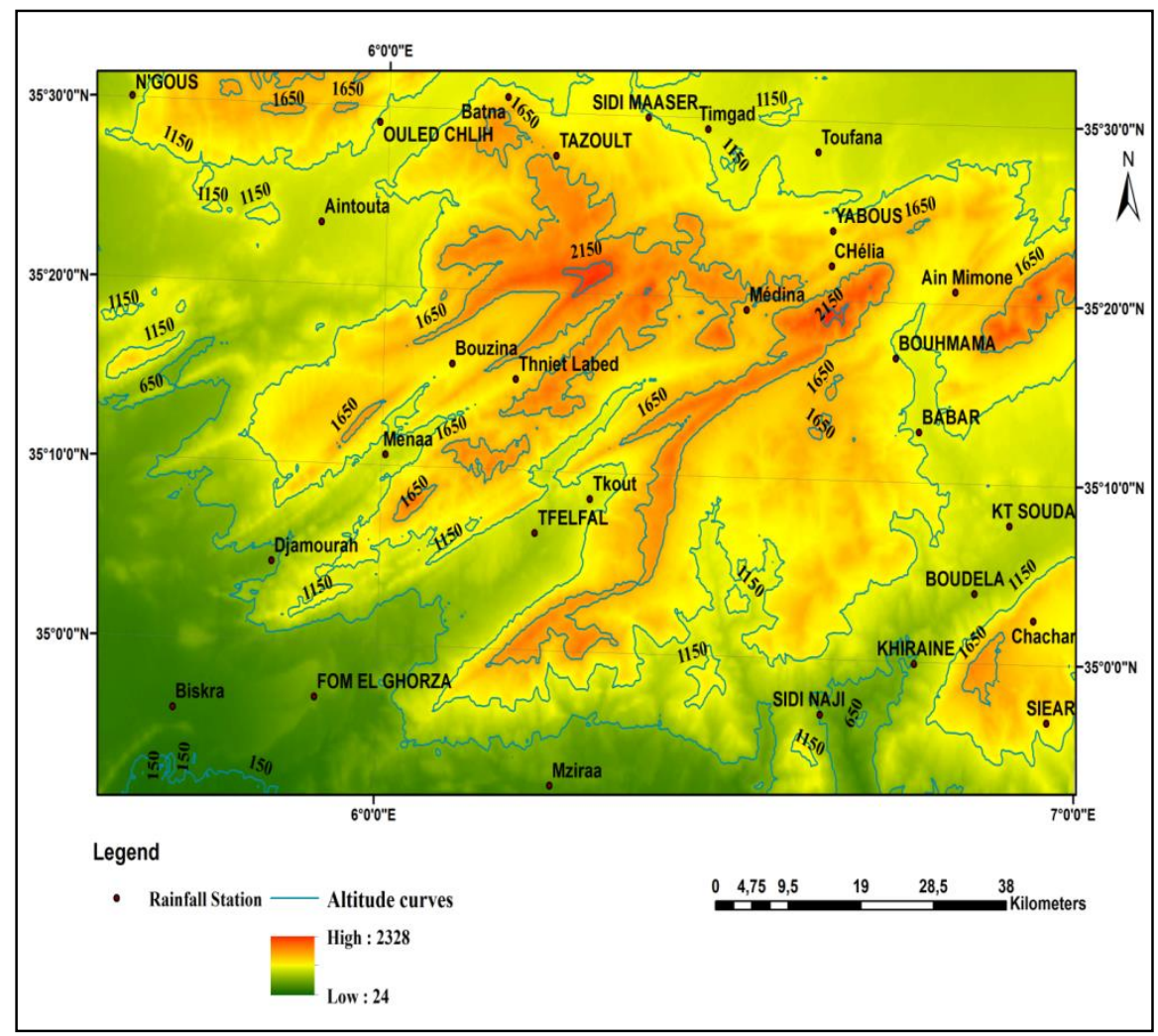

Fig. 2. Map with the pluviometric stations location used in the study.

\subsection{Statistical Analysis}

This study was carried out by the application of the statistical tests of rupture (point of change of time series of precipitation) detection on annual time scale. The choice of this method is based on the robustness of their bases. The tests were carried out with allow to characterize, as well as possible, the evolution of climate parameters; and identify the pivotal years of climate change. KhronoStat software (Boyer, 2002) is adapted to all variables (climatic, hydrological, and meteorological). However, it requires complete series with no gaps. Its choice in this study is justified by the robustness of its tests and also by its success through several similar studies. It can evolve on an annual, monthly or daily scale depending on the needs expressed.

The second test category concerns the homogeneous character of the series (Pettitt test, Buishand test, Hubert test, Bayesian methods or Lee \& Heghinian test): they relate to the 
detection of breaks in a time series. KhronoStat is a statistical model developed by IRD (Research Institute for Development) at the House of Water Sciences (MSE) of Montpellier. It was developed as part of a study on climate variability in West and Central Africa and is oriented on the analysis of hydroclimatic series.

\subsection{Statistical tests}

Pettit's test. Pettit test is a rank-based test for detecting significant changes in the mean of time series data when the exact time of change is unknown .The test is considered robust to changes in the distributional form of time series and relatively powerful compared to Wilcoxon-Mann-Whitney test, cumulative sum and cumulative deviations. Furthermore, Pettitt test has been widely adopted to detect changes in climatic and hydrological time series data.

The null and alternative hypotheses will be reformulated as follows.

Ho: the $\mathrm{T}$ variables follow one or more distributions that have the same location parameter.

Two-tailed test: $\mathrm{Ha}$ - there is a time $t$ when there is a change of location parameter in the variables.

Left-tailed test: $\mathrm{Ha}$ - there is a time $t$ when the location parameter in the variables is reduced by D.

Right-tailed test: Ha - there is a time $t$ when the location parameter in the variable is augmented by D.

The statistic used for the Pettit's test is computed as follows:

$\mathrm{Ut}, \mathrm{n}=\sum_{i=1}^{t} \sum_{j=t+1}^{N} D i j$

$D_{i j}=-1$ if $\left(x_{i}-x_{j}\right)>0, D_{i j}=0$ if $\left(x_{i}-x_{j}\right)=0, D_{i j}=1$ if $\left(x_{i}-x_{j}\right)>0$

Buishand's test. Buishand's test is suitable for variables following any form of distribution whose properties have been mainly studied for the normal case. For this study, Buishand focuses on the case of the two-tailed test and the U statistic. For U statistic, the null and alternative hypotheses are given by;

Ho - the $\mathrm{T}$ variables follow one or more distributions that have the same mean.

Two-tailed test: Ha - there exists a time $t$ when variables change in mean.

$U$ of Buishand is defined by:

$$
\begin{aligned}
& \mathrm{U}=\frac{\sum_{k=1}^{n-1} S_{k} / D_{x}}{n(n+1)} \\
& S_{k}=\sum_{t=1}^{k}\left(\left[\mathrm{X}_{\mathrm{i}}\right]-\overline{\mathrm{X}}\right)
\end{aligned}
$$

where the terms $S_{k}$ and Dx are respectively partial sum and standard deviation given respectively by equations (3) and (4).

In case of rejection of the null hypothesis, no estimate of the break date is proposed by this test. In addition to this procedure, the construction of a control ellipse makes it possible to analyze the homogeneity of the series of $\left(\mathrm{x}_{\mathrm{i}}\right)$. The variable $\mathrm{S}_{\mathrm{k}}$, defined above, follows a normal distribution of zero mean and variance 
$[\mathrm{k}(\mathrm{N}-\mathrm{k}) \sigma 2] / \mathrm{N}, \mathrm{k}=0 \mathrm{~N}$ under the null hypothesis

Hubert Segmentation. The principle of this procedure is to "split" the series into $\mathrm{m}$ segments $(m>1)$ so that the average calculated on any segment is significantly different from the average of the segment (s) neighbours. Such a method is suitable for looking for multiple changes of mean.

Segmentation is defined as follows.

Any series $x_{i}, i=i_{1}, i_{2}$ with $i_{1} \geq 1$ and $i_{2} \leq N$ where $\left(i_{1}<i_{2}\right)$ constitutes a segment of the initial series of $\left(x_{i}\right), i=1 \ldots . . N$.

Any partition of the initial series in $m$ segments is a segmentation of order $m$ of this series. From a particular segmentation of order $m$ practiced on the initial series, we define:

$\mathrm{i}_{\mathrm{k}}, k=1,2, \ldots m$

$* \mathrm{~N} k=\mathrm{I}_{\mathrm{k}}-\mathrm{I}_{\mathrm{k}-1}$

$X_{K}=\frac{\sum_{i=i_{(k-1)}+1}^{i=i_{k}} \mathrm{X}_{\mathrm{i}}}{\mathrm{N}_{\mathrm{K}}}$

$D m=\sum_{K=1}^{K=M} d_{K}$

$d_{k}=\sum^{I=I_{K}}{ }_{i=i_{(k-1)}+1}\left(\left[\mathrm{X}_{\mathrm{i}}-\overline{\mathrm{X}}_{k}\right]\right)^{2}$

The segmentation retained must be such that for a given order $m$ of segmentation, the quadratic difference $\mathrm{Dm}$ is minimum. This condition is necessary but not sufficient for the determination of the optimal segmentation. It must be added to the constraint that the Averages of two contiguous segments must be significantly different. This constraint is satisfied by application of the Scheffé test. For a given segmentation order, the algorithm determine the optimal segmentation of a series that is such that the deviation $D m$ is minimal. This procedure can also be interpreted as a stationary test, the null hypothesis being the studied series is non-stationary. If the procedure doesn't produce acceptable segmentations of order bigger or equal to two, the null hypothesis is accepted

Bayesian method of Lee and Heghinian. The Bayesian method of Lee and Heghinian aims at confirming or invalidating the hypothesis of a change of mean in the series. It is a parametric approach whose application on a series requires a normal distribution of the values of this one. The absence of rupture in the series constitutes the null hypothesis. The procedure is based on the following model:

$X_{i}=\left\{\begin{array}{cc}\mu+\varepsilon_{i} & I=1, \ldots t \\ \mu+\sigma+\varepsilon_{i} & I=\tau+1, \ldots N\end{array}\right.$

where the $\varepsilon_{i}$ are independent and normally distributed, of zero mean and variance $\sigma^{2}$. The variables $\tau, \mu ; \delta$ and $\sigma$ are unknown parameters; $\tau$ and $\delta$ represent respectively the position of the break in time and the amplitude of the change on the average. The possible change (the position and the amplitude) corresponds to the mode of the posterior distributions of $\tau$ and $\delta$.

The method thus provides the probability that the rupture occurs at the moment $\tau$ in a series where it is assumed a priori that there is indeed a change at an indeterminate time. 
Table 1. Detection break results applied to pluviometric series

\begin{tabular}{|c|c|c|c|c|c|c|c|c|}
\hline \multirow[t]{2}{*}{ Station } & \multirow[t]{2}{*}{ Period } & \multicolumn{4}{|c|}{ Segmentation (Hubert) } & \multirow{2}{*}{\begin{tabular}{|l} 
Buichand \\
$\mathrm{H}_{h}$
\end{tabular}} & \multirow{2}{*}{\begin{tabular}{|l|} 
Pettit \\
Year \\
\end{tabular}} & \multirow{2}{*}{\begin{tabular}{|l} 
Lee - Heghinian \\
Year
\end{tabular}} \\
\hline & & Start & End & Mean & Std. & & & \\
\hline Chélia & 1974-2009 & 1974 & 1992 & 536,27 & 95,83 & Rejected & 1992 & 1992 \\
\hline Yabous & 1974-2009 & $\begin{array}{l}1974 \\
1993\end{array}$ & $\begin{array}{l}1992 \\
2009\end{array}$ & $\begin{array}{l}502,28 \\
346,53\end{array}$ & $\begin{array}{l}92,47 \\
100,35\end{array}$ & Rejected & 1992 & 1992 \\
\hline Toufana & 1974-2009 & $\begin{array}{l}1974 \\
1992 \\
\end{array}$ & $\begin{array}{l}1991 \\
2009\end{array}$ & $\begin{array}{l}500,38 \\
342,66\end{array}$ & $\begin{array}{l}94,78 \\
101,27\end{array}$ & Rejected & 1991 & 1991 \\
\hline Bouhmama & 1974-2009 & $\begin{array}{l}1974 \\
1993 \\
\end{array}$ & $\begin{array}{l}1992 \\
2009 \\
\end{array}$ & $\begin{array}{l}530,82 \\
389,92 \\
\end{array}$ & $\begin{array}{l}72,21 \\
90,45\end{array}$ & Rejected & 1992 & 1992 \\
\hline Medina & 1974-2009 & \begin{tabular}{|l|}
1974 \\
1993 \\
\end{tabular} & $\begin{array}{l}1992 \\
2009 \\
\end{array}$ & $\begin{array}{l}474,86 \\
355,10\end{array}$ & $\begin{array}{l}72,96 \\
76,31 \\
\end{array}$ & Rejected & 1992 & 1992 \\
\hline Timgade & 1974-2009 & $\begin{array}{l}1974 \\
1993\end{array}$ & $\begin{array}{l}1992 \\
2009\end{array}$ & $\begin{array}{l}399,84 \\
269,77\end{array}$ & $\begin{array}{l}105,61 \\
71,28\end{array}$ & Rejected & 1992 & 1992 \\
\hline Babar & 1974-2009 & $\begin{array}{l}1974 \\
1992 \\
\end{array}$ & $\begin{array}{l}1991 \\
2009 \\
\end{array}$ & $\begin{array}{l}475,97 \\
264.63 \\
\end{array}$ & $\begin{array}{l}80,61 \\
90.30 \\
\end{array}$ & Rejected & 1991 & 1991 \\
\hline A. Mimoun & 1974-2009 & $\begin{array}{l}1974 \\
1992 \\
\end{array}$ & $\begin{array}{l}1991 \\
2009 \\
\end{array}$ & $\begin{array}{l}471,65 \\
277.76\end{array}$ & $\begin{array}{l}79,57 \\
71.65\end{array}$ & Rejected & 1991 & 1991 \\
\hline S. Mansser & 1974-2009 & \begin{tabular}{|l|}
1974 \\
1992 \\
\end{tabular} & $\begin{array}{l}1991 \\
2009 \\
\end{array}$ & $\begin{array}{l}364,03 \\
199.62\end{array}$ & $\begin{array}{l}64,32 \\
77,86 \\
\end{array}$ & Rejected & 1991 & 1991 \\
\hline Kheiran & 1974-2009 & $\begin{array}{l}1974 \\
1993 \\
\end{array}$ & $\begin{array}{l}1992 \\
2009 \\
\end{array}$ & $\begin{array}{l}310,28 \\
180.87\end{array}$ & $\begin{array}{l}98,70 \\
102.49\end{array}$ & Rejected & 1992 & 1992 \\
\hline Tkout & 1974-2009 & $\begin{array}{l}1974 \\
1992 \\
\end{array}$ & $\begin{array}{l}1991 \\
2009\end{array}$ & $\begin{array}{l}324,87 \\
185,28\end{array}$ & $\begin{array}{l}79,68 \\
55,53\end{array}$ & Rejected & 1991 & 1991 \\
\hline F. Lgherza & 1974-2009 & $\begin{array}{l}1974 \\
1992\end{array}$ & $\begin{array}{l}1991 \\
2009\end{array}$ & $\begin{array}{l}91,70 \\
44,58\end{array}$ & $\begin{array}{l}25,60 \\
14,32\end{array}$ & Rejected & 1991 & 1991 \\
\hline A.Touta & 1974-2009 & $\begin{array}{l}1974 \\
1992\end{array}$ & $\begin{array}{l}1991 \\
2009\end{array}$ & $\begin{array}{l}351,53 \\
228,25\end{array}$ & $\begin{array}{l}78,99 \\
70,95\end{array}$ & Rejected & 1991 & 1991 \\
\hline Biskra & 1974-2009 & $\begin{array}{l}1974 \\
1992 \\
\end{array}$ & $\begin{array}{l}1991 \\
2009 \\
\end{array}$ & $\begin{array}{l}143,41 \\
81.67 \\
\end{array}$ & $\begin{array}{l}27,38 \\
36.29 \\
\end{array}$ & Rejected & 1991 & 1991 \\
\hline Bouzina & 1974-2009 & $\begin{array}{l}1974 \\
1992 \\
\end{array}$ & $\begin{array}{l}1991 \\
2009 \\
\end{array}$ & $\begin{array}{l}303,66 \\
177.55 \\
\end{array}$ & $\begin{array}{l}72,52 \\
52.81 \\
\end{array}$ & Rejected & 1991 & 1991 \\
\hline Menaa & 1974-2009 & \begin{tabular}{|l|l}
1974 \\
1992 \\
\end{tabular} & $\begin{array}{l}1991 \\
2009 \\
\end{array}$ & $\begin{array}{l}323,13 \\
215.56 \\
\end{array}$ & $\begin{array}{l}74,22 \\
55.98 \\
\end{array}$ & Rejected & 1991 & 1991 \\
\hline Tifelfel & 1974-2009 & $\begin{array}{l}1974 \\
1992 \\
\end{array}$ & $\begin{array}{l}1991 \\
2009 \\
\end{array}$ & $\begin{array}{l}250,49 \\
167.86\end{array}$ & $\begin{array}{l}63,39 \\
68.92 \\
\end{array}$ & Rejected & 1991 & 1991 \\
\hline Batna & 1974-2009 & $\begin{array}{l}1974 \\
1992 \\
\end{array}$ & $\begin{array}{l}1991 \\
2009 \\
\end{array}$ & $\begin{array}{l}455,47 \\
260,42\end{array}$ & $\begin{array}{l}64,59 \\
98,13\end{array}$ & Rejected & 1991 & 1991 \\
\hline Chechar & 1974-2009 & $\begin{array}{l}1974 \\
1992 \\
\end{array}$ & $\begin{array}{l}1991 \\
2009 \\
\end{array}$ & $\begin{array}{l}304,55 \\
164.68 \\
\end{array}$ & $\begin{array}{l}89,80 \\
54.34\end{array}$ & Rejected & 1991 & 1991 \\
\hline Djemoura & 1974-2009 & \begin{tabular}{|l|}
1974 \\
1992 \\
\end{tabular} & $\begin{array}{l}1991 \\
2009 \\
\end{array}$ & $\begin{array}{l}159,66 \\
98,57\end{array}$ & $\begin{array}{l}44,036 \\
21,63\end{array}$ & Rejected & 1991 & 1991 \\
\hline Mziraa & 1974-2009 & $\begin{array}{l}1974 \\
1994 \\
\end{array}$ & $\begin{array}{l}1993 \\
2009 \\
\end{array}$ & $\begin{array}{l}60,24 \\
33.71 \\
\end{array}$ & $\begin{array}{l}12,88 \\
14,18 \\
\end{array}$ & Rejected & 1992 & 1993 \\
\hline Kh.S.Nadji & 1974-2009 & $\begin{array}{l}1974 \\
1992 \\
\end{array}$ & $\begin{array}{l}1991 \\
2009 \\
\end{array}$ & $\begin{array}{l}67,54 \\
29.21 \\
\end{array}$ & $\begin{array}{l}14,74 \\
10.38 \\
\end{array}$ & Rejected & 1991 & 1991 \\
\hline TH. Abed & 1974-2009 & $\begin{array}{l}1974 \\
1992 \\
\end{array}$ & $\begin{array}{l}1991 \\
2009 \\
\end{array}$ & $\begin{array}{l}341,77 \\
195,33\end{array}$ & $\begin{array}{l}73,22 \\
55,56\end{array}$ & Rejected & 1992 & 1991 \\
\hline Doucen & 1974-2009 & \begin{tabular}{|l|}
1974 \\
1992 \\
\end{tabular} & \begin{tabular}{|l|}
1991 \\
2009 \\
\end{tabular} & $\begin{array}{l}79,24 \\
45,14\end{array}$ & $\begin{array}{l}35,37 \\
21,70\end{array}$ & Rejected & 1991 & 1991 \\
\hline Merouana & 1974-2009 & $\begin{array}{l}1974 \\
1992 \\
\end{array}$ & $\begin{array}{l}1991 \\
2009 \\
\end{array}$ & $\begin{array}{l}374,47 \\
205.51 \\
\end{array}$ & $\begin{array}{l}63,28 \\
46.77 \\
\end{array}$ & Rejected & 1991 & 1991 \\
\hline Tazoult & 1974-2009 & $\begin{array}{l}1974 \\
1992 \\
\end{array}$ & \begin{tabular}{|l|}
1991 \\
2009 \\
\end{tabular} & $\begin{array}{l}390,37 \\
231.41 \\
\end{array}$ & $\begin{array}{l}71,79 \\
92.24 \\
\end{array}$ & Rejected & 1991 & 1991 \\
\hline Siar & 1974-2009 & $\begin{array}{l}1974 \\
1992 \\
\end{array}$ & $\begin{array}{l}1991 \\
2009 \\
\end{array}$ & $\begin{array}{l}111,00 \\
47,66\end{array}$ & $\begin{array}{l}30,81 \\
18,17\end{array}$ & Rejected & 1991 & 1991 \\
\hline K.Souda & 1974-2009 & $\begin{array}{l}1974 \\
1992 \\
\end{array}$ & \begin{tabular}{|l|}
1991 \\
2009 \\
\end{tabular} & $\begin{array}{l}184,16 \\
110.84 \\
\end{array}$ & $\begin{array}{l}35,92 \\
7,49\end{array}$ & Rejected & 1991 & 1991 \\
\hline Boudela & 1974-2009 & $\begin{array}{l}1974 \\
1992 \\
\end{array}$ & $\begin{array}{l}1991 \\
2009 \\
\end{array}$ & $\begin{array}{l}249,06 \\
156,20\end{array}$ & $\begin{array}{l}33,80 \\
30,27\end{array}$ & Rejected & 1991 & 1991 \\
\hline O.Chlih & 1974-2009 & $\begin{array}{l}1974 \\
1992 \\
\end{array}$ & $\begin{array}{l}1991 \\
2009 \\
\end{array}$ & $\begin{array}{l}377,50 \\
220.27\end{array}$ & \begin{tabular}{|l}
66,96 \\
79.34 \\
\end{tabular} & Rejected & 1991 & 1991 \\
\hline
\end{tabular}




\section{RESULTS AND DISCUSSION}

\subsection{Rain phases and breaks}

The null hypothesis $\mathrm{H}_{0}$ was rejected in the case of rank correlation test (confidence interval $90 \%-95 \%$ ) for all the rainfall stations. The results obtained showed a trend effect between the successive values of certain time series. It has been concluded that these series, which we are going to analyse, are devoid of randomness. The used methods to highlight this rupture were: Buishand's U-statistic, Pettitt's test, Lee and Heghinian's Bayesian method, and Hubert's segmentation method. Break detection results are reported in Table 1.

In all studied zone and for all of the tests, the change-point (rupture) occurred during the years 1991 and 1994 for most pluviometric stations. These rains, in turn, have experienced considerable decrease of more than $40 \%$ for the majority of the stations. The pluviometric deficits during this period are considerable and important and the rainfall values of each station are expressed by a significant and varied standard deviation. The breaks observed were included two separate phases: the first one is dominated by humid influences, while the second presents dry trends.

\subsection{Rainfall index}

To better endow study of arguments, the defined rainfall index was calculated as a reduced centered variable (Lamb, 1982).

$$
S P I=\frac{(\mathrm{Pa}-\mathrm{Pm})}{\sigma \mathrm{p}}
$$

where: $S P I$ is the standardized index of rain of the year $a, P_{a}$ is the pluviometry of the year $a, P_{m}$ is the average annual pluviometry on the reference period 1974-2009 and $\sigma_{p}$ is the standard deviation of the pluviometry on the same reference period.

This index reflects a pluviometric excess or deficit for the considered year relatively to the reference period. It also highlights the intensity of the pluviometric deficit or excess. Pluviometric deficit corresponds to the difference between the rain of a given year and the normal over a long period (36 years in the present study). The tables and the drought index graph were established to confirm both the applied statistical tests for change-points detection and the calculated pluviometric deficit (or excess) they allowed to visualize the dry or humid period after the change-points.

The observation of the available data allowed generating some remarks. The general behaviour of the rainfall regime is centered on the "near normal" category. The frequency of years in this class ranged from 18 to 29 years, or about 51 to $82 \%$ for the entire period from 1974 to 2009, which explains the dominance of this category Table 2. It is interesting to mention that the stations of the arid and semi-arid zone were recorded very low frequency values but with a single rhythm. This observation indicated a fair compensation for wet and dry effects for the whole period. It is noted that the number of years of the two following classes (moderately humid, moderately dry) remains relatively balanced.

The deviation between the humid and dry years seems clearly significant and inclines to the humid influences for all the stations. The most representative example is the case of O. Chlih station. (Table 3). For all the stations, the SPI values were concentrated in the humid categories, but dry years were very limited. 
Table 2. Results of pluviometric index calculation for the period (1974-2009).

\begin{tabular}{|c|c|c|c|c|c|c|c|}
\hline STATION & $\begin{array}{c}<2- \\
\text { Extremely } \\
\text { dry }\end{array}$ & $\begin{array}{c}-1,5 \text { to }-99 \\
\text { Very dry }\end{array}$ & $\begin{array}{c}-1,0 \text { to }-1,49 \\
\text { Moderately } \\
\text { dry }\end{array}$ & $\begin{array}{c}-0,99-0,99 \\
\text { Near to } \\
\text { Normal }\end{array}$ & $\begin{array}{c}1,0-1,49 \\
\text { Moderat. } \\
\text { humid }\end{array}$ & $\begin{array}{c}1,5-1,99 \\
\text { Very } \\
\text { humid }\end{array}$ & $\begin{array}{c}\mathbf{2 , 0} \\
>\begin{array}{c}\text { Extremely } \\
\text { humid }\end{array}\end{array}$ \\
\hline S. NAJI & & 1 & 5 & 25 & 4 & & 1 \\
\hline Babar & & & 6 & 23 & 6 & & 1 \\
\hline Tkout & 1 & 1 & 5 & 22 & 5 & 1 & 1 \\
\hline Tfelfal & & & 10 & 18 & 6 & 1 & 1 \\
\hline F. HORZA & & 1 & 4 & 23 & 5 & 1 & 2 \\
\hline Medina & 1 & 1 & 5 & 23 & 5 & & 1 \\
\hline Chelia & & 1 & 6 & 21 & 5 & 3 & \\
\hline Timgad & 1 & 1 & 2 & 25 & 4 & 1 & 2 \\
\hline Tazoult & & 3 & 1 & 24 & 5 & 3 & \\
\hline S. Maanser & & 2 & 5 & 23 & 4 & 2 & \\
\hline SIEAR & & & 4 & 26 & & 6 & \\
\hline O.Chlih & & 2 & 3 & 21 & 9 & 1 & \\
\hline N'Gaous & & & 5 & 23 & 6 & 1 & 1 \\
\hline Merouan & & & 6 & 23 & 4 & 3 & \\
\hline A.Mimoun & 1 & 2 & 5 & 21 & 4 & 3 & \\
\hline K. souda & & & 3 & 27 & & 5 & 1 \\
\hline Boudela & & 2 & 4 & 23 & 5 & 2 & \\
\hline Kheiran & & & 6 & 24 & 3 & 1 & 2 \\
\hline Bouhmam & 1 & 1 & 3 & 24 & 6 & 1 & \\
\hline Chechar & & & 6 & 24 & 4 & & 2 \\
\hline Th.Abed & & 3 & 3 & 23 & 4 & 2 & 1 \\
\hline Batna & & 3 & 4 & 22 & 7 & & \\
\hline Doucen & & 1 & 1 & 29 & 1 & 2 & 2 \\
\hline Bouzina & & 1 & 5 & 26 & 1 & 1 & 2 \\
\hline Menaa & & 2 & 5 & 22 & 2 & 2 & 3 \\
\hline Djamourah & & & 4 & 25 & 5 & & 2 \\
\hline Biskra & & & 8 & 22 & 3 & 3 & \\
\hline Yabous & & 1 & 5 & 24 & 3 & 3 & \\
\hline A.Touta & & 2 & 5 & 22 & 4 & 3 & \\
\hline A.Baida & & 2 & 7 & 23 & 2 & 2 & \\
\hline Mziraa & 1 & 2 & 3 & 23 & 5 & 1 & 1 \\
\hline Toufana & & 2 & 5 & 23 & 5 & 1 & \\
\hline
\end{tabular}


Table 3. Results of pluviometric index calculation for the period (1992-2009).

\begin{tabular}{|c|c|c|c|c|c|c|c|}
\hline Station & $\begin{array}{l}>\text { to } 2- \\
\text { Extremel } \\
\text { y dry }\end{array}$ & $\begin{array}{l}-1,5 \text { to }-1,99 \\
\text { Very dry }\end{array}$ & $\begin{array}{c}-1,0 \text { to }-1,49 \\
\text { Moderately } \\
\text { dry }\end{array}$ & $\begin{array}{c}-0,99 \text { to } 0,99 \\
\text { Near to normal }\end{array}$ & $\begin{array}{c}1,0 \text { to } 1,49 \\
\text { Moderately } \\
\text { humid }\end{array}$ & $\begin{array}{c}1,5 \text { to } \\
1,99 \\
\text { Very } \\
\text { humide }\end{array}$ & $\begin{array}{c}>\text { To } 2 \\
\text { Extreme } \\
\text { ly } \\
\text { humide }\end{array}$ \\
\hline S. Naji & & 1 & 5 & 12 & & & \\
\hline Babar & & 3 & 3 & 12 & & & \\
\hline Tkout & & 1 & 5 & 12 & & & \\
\hline Tfelfal & & & 9 & 7 & 2 & & \\
\hline F.Ghorza & & 1 & 4 & 13 & & & \\
\hline Médina & 1 & 2 & 3 & 11 & & & 1 \\
\hline Chélia & & 2 & 4 & 10 & & & \\
\hline Timgad & 1 & 1 & 1 & 14 & & & 1 \\
\hline Tazoult & & 3 & 1 & 13 & & 1 & \\
\hline S. Manser & 2 & & 7 & 9 & & & \\
\hline SIEAR & & & 4 & 14 & & & \\
\hline O. chlih & & 3 & 2 & 12 & 1 & & \\
\hline N'gaous & & & 2 & 8 & 3 & 3 & 2 \\
\hline Merouana & & 3 & 3 & 12 & & & \\
\hline $\begin{array}{l}\text { A. } \\
\text { Minoune }\end{array}$ & 1 & & 7 & 10 & & & \\
\hline K.Souda & & & 3 & 15 & & & \\
\hline Boudela & & 2 & 4 & 12 & & & \\
\hline Kheiran & & & 6 & 11 & & & 1 \\
\hline Bouhma & 1 & 1 & 3 & 12 & 1 & & \\
\hline Chahar & & & 6 & 12 & & & \\
\hline Th.Abed & & 2 & 4 & 12 & & & \\
\hline Batna & & 3 & 5 & 10 & & & \\
\hline Doucen & & & 1 & 16 & & & \\
\hline Bouzina & & 1 & 5 & 12 & & & \\
\hline Menaa & & 2 & 4 & 12 & & & \\
\hline Djamoura & & 1 & 3 & 14 & & & \\
\hline Biskra & & 3 & 5 & 9 & & & \\
\hline Yabous & & 3 & 4 & 10 & & & \\
\hline A.Touta & & 3 & 5 & 11 & & & \\
\hline A.Baida & & 2 & 6 & 9 & & & \\
\hline Mziraa & 1 & 2 & 3 & 11 & & & \\
\hline Toufana & & 2 & 5 & 11 & & & \\
\hline
\end{tabular}


More than $50 \%$ of the years are deficient in the second phase for the whole of the representative stations in the massif. Drought years have been started in the end of the year 1991 to date, (Table 3). However, there were sometimes isolated humid years whose annual pluviometry were more than the arithmetic average in the drought period. The figure below (Fig. 3) shows the annual variations of the rainfall index (SPI).

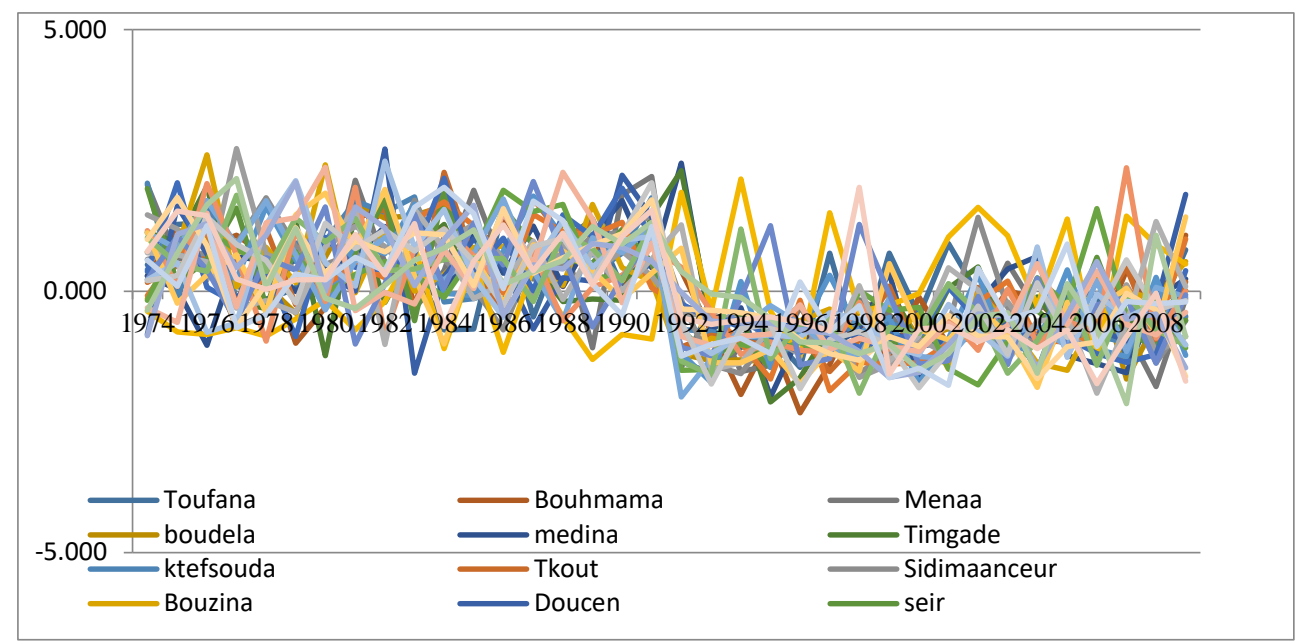

Fig. 3. Pluviometric index values (1974-2009).

It could be noticed that more than $50 \%$ of the years were deficient in the second phase for the whole of the representative stations in the massif (Table 3, Fig. 3). These deficits vary from one year to another and from one station to another according to different proportions. For some stations, the number of the deficient years may reach $70 \%$ especially at the station of Timgad. Then, he graphic representation of SPI allowed to highlight the sequence of the humid years and dry years period (Fig. 3). The SPI values were inclined to humidity in the first phase and steered for drought in the second phase.

\subsection{Spatial distribution of annual rains}

The representation of the rain's distribution was realized starting from a geostatistical approach (simple kriging), the cartographic representation takes into account Hubert's segmentation (annual averages before and after the change-point).

The examination of the Fig. 4, a and b, allows generating the some remarks. The stations located in the North and the North-West mark high values relatively to the Southern stations. The deficient years are gathered under the latitude $35^{\circ}$ (Fig. 4-a). The concave shape clearly indicates the drought extension which seems very important in South northward (rise of the Saharan effects).

Wet trends in some northern stations and in the mid-range recorded a remarkable decline in spatial extension that would be occupied by the extension of southern dry effects: migration of dry effects to the center and the north (the spread of the red colour), (Fig. 4-b). 


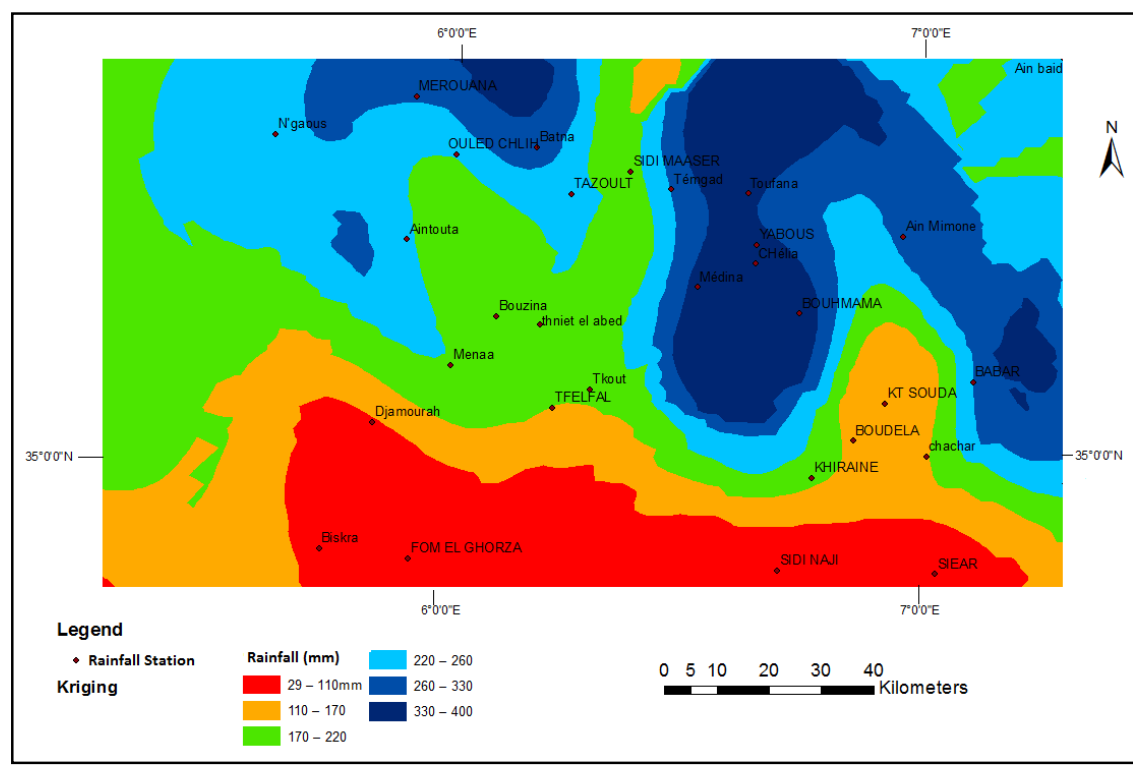

Fig.4- a. Isohyets of the 1974-1991.

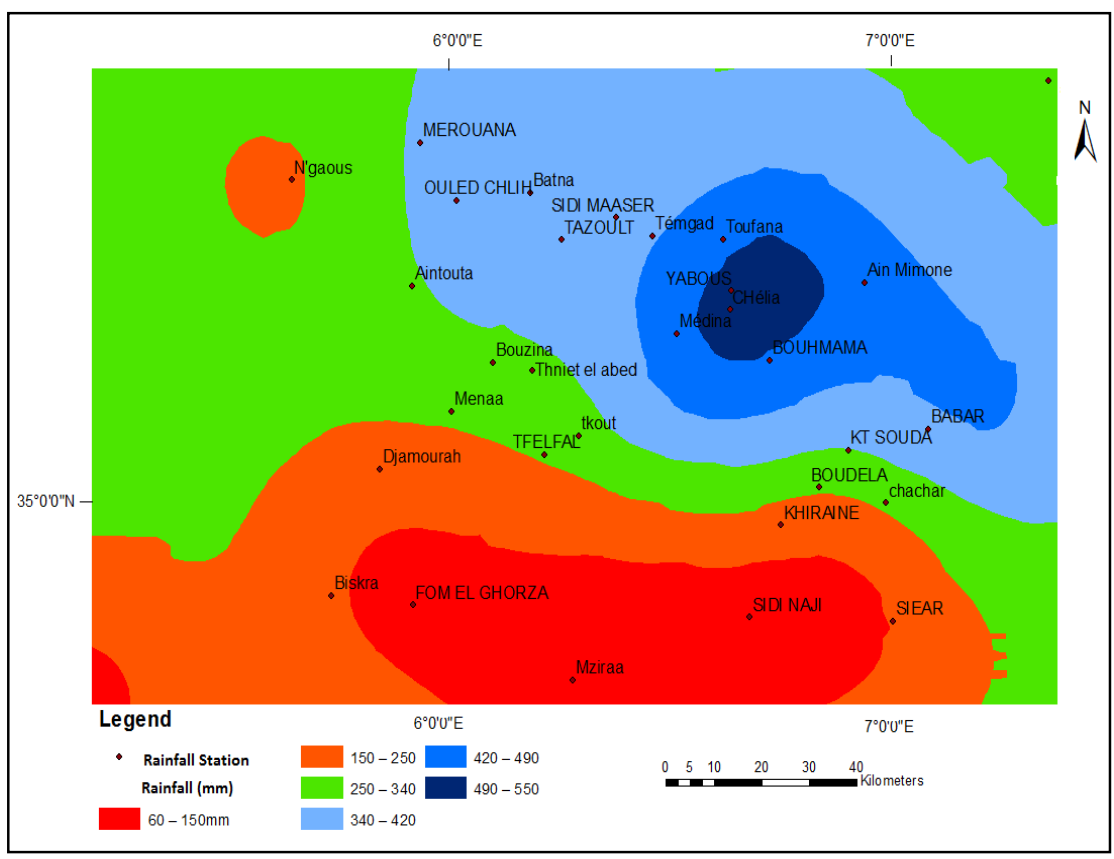

Fig. 4- b. Isohyets of the 1992-2009. 


\section{CONCLUSION}

The study of the rupture allowed to locate a change in the pluviometric regime during the decade 1991-1994 for most studied pluviometric stations. The observed change-points can include two distinct phases; the first one is dominated by humid influences, the second presents dry trends. Precipitation is spread unevenly, both spatially and temporally, in the Mediterranean Sea region (Funatsu et al. 2007; Nastos et al. 2013). Its areal distribution is controlled by both small-scale and large-scale processes. At the large scale, the Mediterranean region is affected both by middle attitude cyclones and subtropical highs (Lionello et al., 2006).

The spatial distribution of precipitation has been established according to the Hubert segmentation algorithm which considers the year of rupture as a separation between two wet and dry phases. This distribution showed a significant decrease in precipitation for the second phase (1992-2009), particularly on the northern part of the massif. The rainfall regime is controlled by the geographic factors effect (Wang et al., 2016.) and the studied zone showed a high variability and accelerated drought.

Obtained results lead us to validate the hypothesis of climatic change and more specifically that a rainfall deficit is being installed at our studied zone. Studying the spatial and temporal variability of precipitation controlled by environmental factors may be helpful for an evaluation of the effect of soil and water conservation.

\section{ACKNOWLEDGEMENT}

Special thanks are extended to Risk and Land Planning Laboratory of the University of Batna 2

\section{R E F E R E N C ES}

Boyer, F. (2002) Logiciel KhronoStat d'analyse statistique de séries chronologique, IRD UR2, Programme 21FRIEND AOC, Equipe Hydrologie UMRGBE, Université de Montpellier II, Ecole des Mines de Paris. http://www.hydrosciences.org/mytech/khronostat.html

Buishand, T.A. (1982) Some methods for testing the homogeneity of rainfall records. Journal of Hydrology, 58 (1-2), 11-27.

Cannarozzo, M, Noto, L.V. \&Viola, F. (2006) Spatial distribution of rainfall trends in Sicily (19212000). Physics and Chemistry of the Earth, 31(18), 1201-1211.

Funatsu, B. M., Claud, C. \& Chaboureau, J.-P. (2007) Potential of advanced microwave sounding unit to identify precipitating systems and associated upper-level features in the Mediterranean region: Case studies, J. Geophys. Res., 112, D17113, doi:10.1029/2006JD008297.

Haidu, I. (2003) Significativité des tendances pluviométriques pluriannuelles. Publication de l'Association Internationale de Climatologie, Université des Sciences et Technologies de Lille, 15, 260-268.

Haidu, I. (2004) Modèle de variabilité climatique indépendant de l'échelle temporelle. In. vol. Climat, mémoire du temps, Actes de XVII-ème Colloque de l'Association Internationale de Climatologie. Université de Caen Basse-Normandie, 43-46.

Haidu, I. \& Magyari-Sàska, Z. (2009) Animated Sequential Trend Signal Detection in Finite Samples. Proceedings of the ITI 200931 st Int. Conf. on Information Technology Interfaces (Ed. LuzarStiffler, V; Jarec, I; Bekic, Z), June 22-25, 2009, Cavtat, Croatia.

Hubert, P. (2000) The segmentation procedure as a tool for discrete modelling of hydrometeorological regimes, Stoch. Environ. Res. Risk. Assess., 14 (4-5), 297-304.

Jansky, L., Ives, J.D., Furuyashiki, L. \& Watanabe, L. (2002) Global mountain research for sustainable development. Global Environmental Change, 12, 231-239. 
Khon, V.C, Mokhov I.I., Roeckner, E. \& Semenov, V.A. (2007) Regional changes of precipitation characteristics in northern Eurasia from simulations with global climate model. Global and Planetary Change, 57(1-2), 118-123.

Labat, D. (2005) Recent advances in wavelet analyses. Part I: A review of concepts. Journal of Hydrology 314 (1-4), 275-288.

Lamb, P. J. (1982) Persistence of sub-Saharan drought. Nature, 299, 46-47.

Lionello, P., Malanotte-Rizzoli, P. \& Boscolo, R. - Editors, (2006) Mediterranean Climate Variability. Vol. 4, Elsevier, ISBN: 9780444521705,438 pp.

Nastos, P., Kapsomenakis, J. \& Douvis, K. (2013) Analysis of precipitation extremes based on satellite and high-resolution gridded data set over Mediterranean basin, Atmos. Res., 131, 4659, doi:10.1016/j.atmosres. 04.009.

Pauling, A., Luterbacher, J., Casty, C. \& Wanner, H. (2006) Five hundred years of gridded highresolution precipitation reconstructions over Europe and the connection to large-scale circulation. Climate Dynamics 26(4), 387-405.

Le Quesne, C., Stahle, D.W., Cleaveland, M.K., Therrell, M.D., Aravena, J.C. \& Barichivich, J. (2006) Ancient Austrocedrus tree-ring chronologies used to reconstruct central Chile precipitation variability from a.d. 1200 to 2000. Journal of Climate 19, 5731- 5744 .

Santos, J.A., Corte-Real, J., Ulbrich, U., \& Palutikof, J. (2007) European winter precipitation extremes and large-scale circulation: a coupled model and its scenarios. Theoretical and Applied Climatology, 87(1-4), 85-102.

Semenov,V. \& Bengtsson, L. (2002) Secular trends in daily precipitation characteristics: greenhouse gas simulation with a coupled AOGCM. Climate Dynamics, 19(1-4), 123-140.

Wang, J.F., Zhang, T.-L. \& Fu, B.-J. (2016) A measure of spatial stratified heterogeneity. Ecological Indicators, 67, 250-256.

Xoplaki, E., Rouco, J.F.G., Luterbacher, J., \& Wanner, H. (2004) Wet season Mediterranean precipitation variability: Infuence of large-scale dynamics and trends. Climate Dynamics 23(1), 63-78. 